\title{
Graduate Employability Skills: Differences between the Private and the Public Sector in South Africa
}

\author{
P Jonck* \\ PhD (Psychology), BSocSc (Hons) (Industrial Psychology), Deputy Director: Research and Policy Unit, \\ Department of Community Safety, Gauteng Provincial Government \\ petrojonck@hotmail.com / petronell.jonck@yahoo.com
}

F van der Walt

PhD (Organisational Behaviour), Faculty Administrator, Faculty of Management Sciences, Central University of Technology, Free State

Email: fvdwalt@cut.ac.za

\section{Doi:10.5901/mjss.2015.v6n3s2p345}

\section{Abstract}

The article reports on a comparison between the private and the public sector with reference to an evaluation of employability skills of graduates in a sample consisting of employers from the Mangaung area, South Africa. A quantitative study was conducted using an unabridged questionnaire, with a Cronbach's alpha of .97 and an inter-item correlation of .405340. The sample consisted out of 250 private-sector and 253 public-sector respondents. The results indicate that the only statistically significant differences between the private and the public sector in terms of graduate employability skills are self-responsibility and interpersonal skills. Indicative of the notion that the differences between the private and the public sector are becoming less marked, and that the employability skills that are sought by the public sector are similar to those that are sought by the private sector. Based on the findings of the research project, recommendations are made concerning course curricula in order to ensure that graduates are employable irrespective of sector.

Keywords: Employability; employers; graduate attributes; critical cross-field outcomes.

\section{Introduction}

Education is vital in the knowledge economy as the commodity of knowledge is gaining accreditation, replacing raw materials as the most critical input for determining a country's ability to compete in the world economy (Yabuuchi \& Chaudhuri, 2009). As such, Woldegiorgis, Jonck and Goujon (2015) as well as Babes (2009) asserted that ascribed to globalization the major economies are knowledge-based with elevated levels of skills, education, lifelong learning, and innovation. Moreover, in recent years the function of higher education has been increasingly tied to economic growth and national productivity (Cummings, 2010). Consequently, a key function of higher education is to increase the total factor productivity of a country, inducing growth, and ultimately reducing poverty (Jonck, 2014; Le Van, Nguyen, Nguyen \& Luong, 2010). Due to the emphasis on education by the South African Government, higher education is under increasing pressure to validate its function and to clearly demonstrate the output from the public funds that it consume, with growing calls for accountability (Backhouse, 2010; Campbell, 2010).

The before mentioned, underscore the importance of employability, which is currently an international concern ascribed to graduate unemployment (Jonck, 2014). In the South African context it is a contentious issue that is debated in various circles subsuming government, the labour market, educational institutions as well as the private and public sector (Bester \& Boshoff, 2009). Employability has been investigated in various countries, such as India (Mohan, 2013), Taiwan (Pan \& Lee, 2011), Nigeria (Asuquo \& Inaja, 2013), and the United Kingdom (Benson, Morgan \& Filippaios, 2013; Marais \& Perkins, 2013) to mention a few. Research into the role of employability in the context of higher education has gain prominence in the first decade of the 21st century (Rivera, Gallego, Álvarez, Inchaurtieta, Albizuri \& Alvarez du Eulate, 2012). What's more, previous research mainly focused on the identification of skills and competencies that graduates require to be deemed employable (Ahmad, 2005; Asuquo \& Inaja, 2013; Freire et al., 2011; Kathleen, 2005). The rationale underlying the aforementioned studies is the contention that higher education institutions often emphasises skills that are not in demand by employers (Garicia \& Mora, 2004). Research conducted by Hinchliffe and Jolly (2011), 
referring to the work of Cranmer (2006), concluded that there was no statistically significant relationship between the provision of enhanced skills at higher education institutions and increased probability of employment. As a result, the efficacy of skills provision in higher education is called into question, as employers' voice concern over the employability of graduates (Cummings, 2010; Hinchliffe \& Jolly, 2011). Furthermore, Asuquo and Inaja (2013) noted that the majority of research investigating employability from the employers' perspective has been qualitative in nature.

Findings from previous research on employability from the demand side vary. According to Benson, Morgan and Fillipaios (2013) social skills and inherent personality traits are deemed as more important than technical skills or a degree qualification as these traits are pivotal to ensure career development. While, Asuquo and Inaja (2013) reported that continuous learning, networking, teamwork, persistence, organizational skills, risk taking, optimism, and flexibility were the most important qualities that graduates should possess. Freire, Álvares and Montez (2011) found that other competencies, such as communication, leadership, customer service, understanding, and emotional intelligence, were the most valued competencies needed for work performance. While, Rivera and colleagues (2012) asserted that the most valued characteristics needed to find employment are related to interpersonal skills, teamwork, people skills, responsibility, effort, and willingness to learn. Thus, one may conclude that although authors agree that skills other than subject content are essential for securing and maintaining employment, the individual skills, competencies, and personality traits that have been identified in different countries as being pivotal are not universal.

For the sake of clarity, employability from the demand said refers to knowledge, skills, attitudes, and commercial understandings that enable graduates to contribute meaningfully to the achievement of organisational objectives after commencement of duties (Omar, Manaf, Mohd, Kassim \& Aziz, 2012). Knowledge specifically refers to the basic theories, concepts, models, and facts that constitute the core content of an academic discipline (Hennemann \& Liefner, 2010). Skills, on the other hand, subsume the ability to master the methods that are utilised within a particular disciplinary field. Competence is defined as the ability to use both knowledge and skills in the context of the labour market, and it would include attitudes and commercial understandings. Crossman and Clarke (2010) regard employability as a psycho-social construct that comprises a range of individual characteristics, facilitating adaptive overt behaviour to maintain ongoing employment in a rapidly changing economic landscape. For the purposes of this article, employability will be seen as having four broad interrelated components, namely skilful practices (communication, and management of time, self, and resources), specialisation in a field of knowledge (academic skills), Self-efficacy subsuming personal identity and selfworth, and meta-cognition (self-awareness, and the ability to reflect on actions) as defined by Yorke and Knight (2006). In discourse emanating from South Africa, these components of employability are similar to the notion of applied competence (Parker \& Griesel, 2009).

Despite the fact that authors often refer to employability skills as universal and competencies that are needed, irrespective of job category and level (Ju Zhang \& Pacha, 2012) it is worth asking whether the public and private sector require the same employability skills, ascribed to the dissimilar business philosophies that underpin these two sectors. Numerous research studies have focused on the private sector, with a paucity of studies having investigated employability in the public sector (Selvadurai, Choy \& Maros, 2012). As such, Kroukamp (2007) and Chelechele (2009) argue that higher education, as the responsible party for fostering competencies and skills, should take cognisance of and adopt curricula to address the demands and realities faced by public servants. Research as to how the skills demand between the public and private sector differ within the South African context could however not be found. Against this background, the current study sought to compare graduate employability skills across the public and the private sector. The secondary objective is to determine how the two respective sectors evaluated graduates' employability skills.

\section{Theoretical Framework}

Various theories have been used as theoretical framework in different disciplines to underpin the employability debate. Within the field of Sociology of Education, two theoretical paradigms have been highlighted in previous research, namely the consensus and the conflict theory on graduate employability (Selvadurai et al., 2012). The consensus theory focuses largely on stability within society and the socialization of community members into norms and values on which society agrees upon. As such, individuals and social institutions work in conjunction, or in consensus, to sustain equilibrium (Matsepe, 2002). The consensus theory of employability is based on the belief that human capital injection through generic skills development will ensure employability of graduates and accelerated career development (Selvadurai et al., 2012).

Scholars that subscribe to the conflict theory of employability take into consideration the fact that society is characterised by inequalities in wealth, power, as well as status, and that these inequalities create conflict between individuals and social groups (Matsepe, 2002). This theoretical paradigm underscores the employer-academia conflict 
and argues that employability cannot be the sole prerogative of higher education institutions. Consequently, employers should assume responsibility for providing workplace experiences that will increase employability (Selvadurai et al., 2012). However, employers face the overwhelming challenge of reacting to a rapidly changing external environment which is crucial to the survival of organisations at large (Stice, 2011). For this reason, employers expect graduates to be workplace-ready (Omar et al., 2012).

When considering employability from a Business Management Perspective two theories come to the fore namely the human development and human capital theory (Jonck, 2014). The first mentioned consider employability from the supply side and focus on a variation of skills including but not limited to knowledge generation, professional preparation, cultural knowledge and the enlightenment of the public sphere (Jonck, 2014; McLean, Abbas \& Ashwin, 2012). The human capital theory underscores education as a primary economic enabler (Bridgstock, 2009) in which labour is seen as a factor of production (Mohr \& Seymore, 2012). Within the framework of the human capital theory, the term human capital refers to the quality of labour, thus the skills, knowledge and health of employees (Morh \& Seymore, 2012). Consequently, it can be deduced that the term human capital is similar to the definition of employability skills which refers to the knowledge, skills and commercial understanding of labour (Omar et al. 2012).

\section{Method}

The primary aim of the study was to compare the private and the public sector in respect of their evaluation of graduates' employability skills in the Manaung area of the Free State Province in South Africa.

\subsection{Participants}

The respondents represented small and medium-sized enterprises, large organisations, and public sector bodies, predominantly from the central region of South Africa. Only those in management positions were included in the sample ascribed to the fact that the perspectives of employers were elicited. A total of 503 questionnaires were received from a variety of employers, equally divided between the private and the public sector. The private sector included the industries of finance and banking, construction, logistics and transportation, hospitality, service delivery, and other miscellaneous industries. The respondents held a variety of positions, including human resources (HR) manager, head of department $(\mathrm{HOD})$, line manager, and sole proprietor. The fact that the respondents reflected a broad range of organisational structures enabled the voice of employers to emerge across organisational size and structure. A comprehensive description of the demographic composition of the sample is discussed in the following section.

\subsection{Research design}

An embedded mixed method approach was utilised to obtain insights into employers' evaluation of graduates' employability skills. De Lisle (2011) traced the usage of dual methodologies within organizational research back to Jick (1979). The reason for using mixed method research designs can be attributed to the stance that in applied Social Sciences, there are "complex and multiplex social phenomena that are not amenable to single frame probing" (De Lisle, 2011: 89). Although the study utilized an embedded mixed method research design this paper only report on the quantitative results as part of a larger research project.

Two characteristics of the research design under discussion were that it was a cross-sectional and an ex post facto research design. The research design was cross-sectional in that data collection took place at a single point in time, without repeat measures, and no experimental intervention took place. The research design was ex post facto by virtue of the fact that respondents belonged to the different independent variables prior to the commencement of the study. Moreover, both quantitative and qualitative data were sourced in that respondents were given the opportunity to identify additional skills deemed important to participants that were not included in the questionnaire.

\subsection{Data collection instrument}

An unabridged questionnaire based on an employability skills model that was developed as part of a doctoral study, with a reliability of .97 and an inter-item correlation of .405340 (De Jager, 2004), was used to collect the data. The selfadministered questionnaire consisted of three sections, covering biographical variables, critical cross-field outcomes, and graduate attributes, respectively. The critical cross-field outcomes evaluated included problem-solving skills, teamwork, self-responsibility, research skills, communication, technological and environmental literacy, and the development of 
macro-vision skills. Graduate attributes that were evaluated included job-seeking skills, academic skills, personal and career management, interpersonal skills, work ethic, and computer literacy. Both the critical cross-field outcomes and the graduate attributes were measured using a four-point Likert scale, where the points ranged on a continuum from complete disagreement to complete agreement, represented by the numbers 1 to 4 , in that order. A supplementary openended question was included to provide respondents with the opportunity to identify any employability skills that had not been mentioned in the questionnaire.

Jonck and Minnaar (2015: 230) validated the measuring instrument for the Faculty of Management Sciences and found by means of both exploratory and confirmatory factor analysis that four factors were responsible for the majority of the variance. The four underlying factors subsumed interpersonal skills, Critical Cross Field Outcomes, job-related activities and academic skills which accounted for $42.297 \%$ of the variance in perceived employer evaluation of graduates' employability skills. The total questionnaire accounted for $61.745 \%$ of the variance (Jonck \& Minnaar, 2015 : 233). Alpha estimates for the subscales ranged from 0.863 to 0.922 . Additionally, maximum likelihood and robust statistics found that the model used was a good fit (Jonck \& Minnaar, 2015: 235).

\subsection{Procedure}

Seeing as one of the employability skills required of graduates is research skills, students from a Research Methodology class at a local higher education institution were used as fieldworkers. As such, the questionnaire and consent form were posted on an e-learning site and the fieldworkers had to each go to 5 organizations to complete 5 questionnaires for additional marks. To ensure the credibility of this procedure each survey had to be stamped by the organization, although the participants remained anonymous. Without the stamped signed consent form the questionnaire was omitted from the final sample.

\subsection{Data analysis}

Cronbach's alpha coefficients were used to determine the reliability of the measuring instrument, which ranged from .86 for Section B to .97 for Section C, and .97 for the scale as a whole. Descriptive statistical analysis comprising of frequencies, percentages, the median, mean and standard deviation was carried out. Inferential statistical analysis was performed with the use of a T-test for independent means to determine the statistically significant differences between the private and the public sector.

\subsection{Ethical considerations}

Ethical guiding principles were complied with, in that a letter of consent had to be signed by each respondent. The letter stated that participation was voluntary and anonymous, thereby ensuring confidentiality of the respondents. The respondents were informed of the aims, purpose, and intended uses of the research project, and full particulars of the principal researcher were given. No physical or psychological harm was caused as a result of participation in the project (May, 2011).

\section{Results}

To contextualise the findings Table 1 overleaf illustrates the demographic composition of the sample in each sector. As can be seen from Table 1, the majority of respondents working in the public sector were line managers $(n=153 ; 61.2 \%)$ followed by human resources managers or officers $(n=59 ; 23.6 \%)$ and Head of Departments $(n=19 ; 7.6 \%)$. In the private sector, the majority of the respondents were also line managers $(n=125 ; 49.4 \%)$, followed by human resources managers or officers $(n=41 ; 16.2 \%)$ and Brach managers $(n=38 ; 15.0 \%)$. With regard to age, the majority of the respondents in the public sector were between $30-39$ years $(n=114 ; 45.6 \%)$ and $40-49$ years $(n=88 ; 35.2 \%)$. This was also the case in the private sector, where 117 respondents (46.3\%) were between 30-39 years, and 76 respondents (30\%) were between 40-49 years. In terms of gender, the sample from the public sector consisted of 142 males (56.8\%) and 108 females (43.2\%), and the private sector sample consisted of 148 males (58.5\%) and 105 females (41.5\%). With regard to academic qualifications, most respondents in the public sector sample had a diploma or a degree $(n=142$; $56.8 \%)$, as was the case in the private sector sample $(n=141 ; 55.7 \%)$. 
Table 1: Demographic composition of the respondents per sector $(n=503)$

\begin{tabular}{|c|c|c|c|c|c|}
\hline Variable & Sector & Level of the variable & $\mathrm{n}$ & $\%$ & Cumulative $\%$ \\
\hline \multirow{10}{*}{ 음 } & \multirow{5}{*}{ Public Sector } & HR manager/officer & 59 & 23.6 & 23.6 \\
\hline & & Branch manager & 18 & 7.2 & 30.8 \\
\hline & & HOD & 19 & 7.6 & 38.4 \\
\hline & & Line manager & 153 & 61.2 & 99.6 \\
\hline & & Sole proprietor & 1 & 0.4 & 100 \\
\hline & \multirow{5}{*}{ Private Sector } & HR manager/officer & 41 & 16.2 & 16.2 \\
\hline & & Branch manager & 38 & 15.0 & 31.2 \\
\hline & & HOD & 26 & 10.3 & 41.5 \\
\hline & & Line manager & 125 & 49.4 & 90.9 \\
\hline & & Sole proprietor & 23 & 9.1 & 99.2 \\
\hline \multirow{10}{*}{$\stackrel{\mathscr{Q}}{\leftarrow}$} & \multirow{5}{*}{ Public Sector } & 20-29 years & 28 & 11.2 & 11.2 \\
\hline & & 30-39 years & 114 & 45.6 & 56.8 \\
\hline & & 40-49 years & 88 & 35.2 & 92.0 \\
\hline & & $50-59$ years & 17 & 6.8 & 98.8 \\
\hline & & $60+$ years & 3 & 1.2 & 100 \\
\hline & \multirow{5}{*}{ Private Sector } & 20-29 years & 43 & 17.0 & 17.0 \\
\hline & & 30-39 years & 117 & 46.2 & 63.2 \\
\hline & & $40-49$ years & 76 & 30.0 & 93.3 \\
\hline & & $50-59$ years & 12 & 4.7 & 98.0 \\
\hline & & $60+$ years & 5 & 2.0 & 100 \\
\hline \multirow{4}{*}{$\begin{array}{l}\stackrel{\mathcal{D}}{\mathbb{D}} \\
\stackrel{\overline{2}}{\mathbb{D}}\end{array}$} & \multirow{2}{*}{ Public Sector } & Male & 142 & 56.8 & 56.8 \\
\hline & & Female & 108 & 43.2 & 100 \\
\hline & \multirow{2}{*}{ Private Sector } & Male & 148 & 58.5 & 58.5 \\
\hline & & Female & 105 & 41.5 & 100 \\
\hline \multirow{10}{*}{ 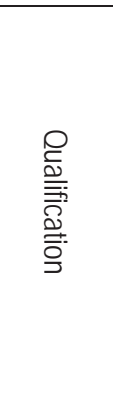 } & \multirow{5}{*}{ Public Sector } & Grade 12 & 16 & 6.4 & 6.4 \\
\hline & & Diploma/degree & 142 & 56.8 & 63.2 \\
\hline & & Honours degree & 59 & 23.6 & 86.8 \\
\hline & & Master's degree & 29 & 11.6 & 98.4 \\
\hline & & $\mathrm{PhD}$ & 4 & 1.6 & 100 \\
\hline & \multirow{5}{*}{ Private Sector } & Grade 12 & 22 & 8.7 & 8.7 \\
\hline & & Diploma/degree & 141 & 55.7 & 64.4 \\
\hline & & Honours degree & 69 & 27.3 & 91.7 \\
\hline & & Master's degree & 18 & 7.1 & 98.8 \\
\hline & & $\mathrm{PhD}$ & 3 & 1.2 & 100 \\
\hline
\end{tabular}

Table 2 and Table 3 below illustrate the measures of central tendency for the Critical Cross-field Outcomes (CCFO's) and the Graduate Attributes (GA's) per sector.

Table 2: Measures of central tendency for the critical cross-field outcomes (CCFO's) and the graduate attributes (GA's) for the public sector

\begin{tabular}{|c|c|c|c|c|c|c|c|}
\hline \multicolumn{2}{|c|}{ Variable } & Level of the variable & Lower quartile & Upper quartile & Median & - & SD \\
\hline \multirow{13}{*}{ 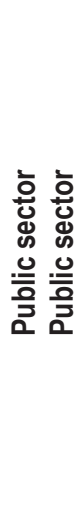 } & \multirow{7}{*}{ CCFO's } & Problem solving & 3 & 4 & 3 & 3.01 & 0.776 \\
\hline & & Teamwork & 3 & 4 & 3 & 3.22 & 0.758 \\
\hline & & Self-responsibility & 3 & 4 & 3 & 3.10 & 0.770 \\
\hline & & Research skills & 3 & 4 & 3 & 2.98 & 0.850 \\
\hline & & Communication & 3 & 4 & 3 & 3.17 & 0.754 \\
\hline & & Technological and environmental literacy & 2.75 & 4 & 3 & 2.98 & 0.801 \\
\hline & & Macro-vision skills & 2 & 3 & 3 & 2.75 & 0.847 \\
\hline & \multirow{6}{*}{ Ga's } & Job-seeking skills & 2.83 & 3.50 & 3.08 & 3.09 & 0.579 \\
\hline & & Academic skills & 2.63 & 3.25 & 3 & 2.97 & 0.548 \\
\hline & & Personal/career management & 2.64 & 3.27 & 2.82 & 2.95 & 0.533 \\
\hline & & Interpersonal skills & 2.70 & 3.50 & 3 & 3.08 & 0.560 \\
\hline & & Work ethic & 2.60 & 3.60 & 3 & 3.02 & 0.662 \\
\hline & & Computer literacy & 3 & 4 & 3 & 3.37 & 0.640 \\
\hline
\end{tabular}


Table 3: Measures of central tendency for the critical cross-field outcomes (CCFO's) and the graduate attributes (GA's) for the private sector

\begin{tabular}{|c|c|c|c|c|c|c|c|}
\hline \multirow{13}{*}{ 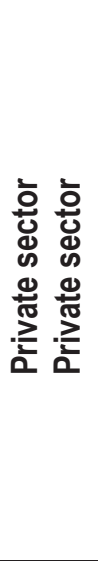 } & \multirow{7}{*}{ CCFO's } & Problem solving & 2 & 3 & 3 & 2.92 & 0.722 \\
\hline & & Teamwork & 3 & 4 & 3 & 3.23 & 0.719 \\
\hline & & Self-responsibility & 2 & 4 & 3 & 2.93 & 0.81 \\
\hline & & Research skills & 2 & 3.5 & 3 & 2.87 & 0.872 \\
\hline & & Communication & 3 & 4 & 3 & 3.10 & 0.773 \\
\hline & & Technological and environmental literacy & 2 & 4 & 3 & 2.97 & 0.814 \\
\hline & & Macro-vision skills & 2 & 3 & 3 & 2.70 & 0.764 \\
\hline & \multirow{6}{*}{ Ga's } & Job-seeking skills & 2.67 & 3.50 & 3 & 3.07 & 0.543 \\
\hline & & Academic skills & 2.63 & 3.25 & 2.88 & 2.93 & 0.511 \\
\hline & & Personal/career management & 2.64 & 3.27 & 2.82 & 2.92 & 0.502 \\
\hline & & Interpersonal skills & 2.60 & 3.40 & 3 & 2.98 & 0.548 \\
\hline & & Work ethic & 2.60 & 3.40 & 3 & 2.96 & 0.617 \\
\hline & & Computer literacy & 3 & 4 & 3 & 3.27 & 0.696 \\
\hline
\end{tabular}

The measures of central tendency for each sector, shown in Table 2 and 3, indicated that respondents from both the public and the private sector were reasonably satisfied with the critical cross-field outcomes that are currently embedded in all higher education curricula. The critical cross-field outcome that respondents from both the public and the private sector were most satisfied with was teamwork. Respondents from both sectors were least satisfied with the development of macro-vision skills, which refers to demonstrating an understanding of the world as a set of interrelated systems, by recognising that problem solving does not occur in isolation. In terms of graduate attributes, respondents from both the private and the public sector were most satisfied with computer literacy and least satisfied with personal or career management.

To test the main hypothesis of the paper that was: "There is no statistical significant difference between the public and the private sector in terms of the employability skills required by employers" a T-test was performed with results depict in Table 4 below.

Table 4: T-test results for the two sectors and the dependent variables critical cross-field outcomes and graduate attributes (Equal variances not assumed)

\begin{tabular}{|c|c|c|c|c|}
\hline Variable & Level of the variable & F value & DF & p-value \\
\hline \multirow{6}{*}{ CCFO's } & Problem solving & 0.028 & 497.451 & 0.174 \\
\cline { 2 - 5 } & Teamwork skills & 0.098 & 498.920 & 0.936 \\
\cline { 2 - 5 } & Self-responsibility & 1.470 & 498.095 & $0.015^{\star}$ \\
\cline { 2 - 5 } & Research skills & 2.401 & 500.912 & 0.151 \\
\cline { 2 - 5 } & Communication skills & 0.183 & 500.920 & 0.283 \\
\cline { 2 - 5 } & Technological and environmental literacy & 0.136 & 500.995 & 0.871 \\
\cline { 2 - 5 } & Development of macro vision & 2.977 & 494.532 & 0.467 \\
\hline \multirow{4}{*}{ Graduate attributes } & Job-seeking skills & 0.502 & 498.136 & 0.630 \\
\cline { 2 - 5 } & Academic skills & 1.080 & 497.610 & 0.426 \\
\cline { 2 - 5 } & Personal/career management & 0.832 & 498.349 & 0.634 \\
\cline { 2 - 5 } & Interpersonal skills & 0.179 & 500.434 & $0.040^{\star}$ \\
\cline { 2 - 5 } & Work ethic & 3.583 & 497.549 & 0.297 \\
\cline { 2 - 5 }
\end{tabular}

${ }^{*} p \leq 0.05$

Table 4 indicated that the private and public sectors were statistically significantly differed from each other only in respect of the evaluation of self-responsibility and interpersonal skills on the 95 percentile. Self-responsibility refers to the ability of an individual to organise and manage themselves and their activities responsibly and effectively (Ramphele, as cited in De Jager, 2004). Interpersonal skills is defined as dealing effectively with others, having hazel free interaction as well as positive relationships with people (DuBrin, as cited in De Jager, 2004). None of the other critical cross-field outcomes or graduate attributes showed any statistically significant difference on either the $95^{\text {th }}$ or the $99^{\text {th }}$ percentile. Interestingly enough, it would seem as if the public sector participants evaluated the graduates' employability skills specifically related 
to self-responsibility and interpersonal skills in a less favourable light than the private sector as seen in Table 2 and 3.

\section{Discussion of Results}

The results of the study have indicated that the private and the public sector require mostly the same employability skills from graduates in order to be employable in both these sectors. In addition, the public sector respondents evaluated graduates employability skills with reference to self-responsibility and interpersonal skills in a less favourable light that participants from the private sector. These results are in accordance with findings from Bester and Boshoff (2009) who indicated that public sector managers identified interpersonal skills, self-discipline, time management, and an internal locus of control as some of the skills lacking in graduates entering the public sector. In addition, Chelechele (2009) noted that poor service delivery is a result of inefficiency and ineffectiveness in the public sector with the last mentioned as a result of a lack of skills. Consequently, the hypothesis is rejected with specific reference to interpersonal skills and selfresponsibility. Because the world of work is continually changing, it is important that higher education institutions continue to develop course curricula to include relevant employability skills (Alibeigi \& Zarafshani, 2006). Although technical skills have previously been sufficient to find a job, the current situation has changed, ascribed to globalisation, technological advances, skills shortages and a scarcity of jobs, particularly in South Africa.

From the findings one can also conclude that differences between the private and the public sector in terms of graduate requirements are decreasing. This may be attributed to changes in the two different business philosophies that have traditionally underpinned these sectors. Ascribed to changes in the external environment and increased pressure from communities in terms of service delivery, both the private and the public sector are increasingly moving towards a business model that focuses on providing quality service to consumers. Therefore, it is not surprising that only minor differences currently exist between these two sectors in terms of employability skills. It is important that higher education respond appropriately to the changes that are occurring within the two sectors, because they are training and preparing graduates for entry into these sectors.

\section{Recommendation}

It is recommended that higher education institutions, and specifically qualifications in public administration, should place stronger emphasis on research skills in undergraduate programmes. The presentation and assimilation of knowledge by students in different formats, including oral presentation of information, should be encouraged and examined. Information should also be innovatively re-contextualised in all subjects. Furthermore, it is recommended that a generic business administration subject should be developed and incorporated into the curriculum, focusing on customer service, telephone etiquette, punctuality, and work ethic. In addition to this, soft skills also need to be considered. Soft skills are defined as "those skills - over and above technical knowledge and expertise in the chosen field - required for an individual to related to and survive and succeed in his or her environment" (Ramesh \& Ramesh, 2010). Some soft skills which should form part of curricula are emotional intelligence, problem-solving skills, stress management skills, time management skills, and career self-assessment skills. Although social media skills were not evaluated in this research project, Benson, Morgan and Filippaios (2014) assert that social media skills are becoming increasingly important, and that they should be built into the learning experience at higher education level.

\section{Conclusion}

Worldwide, higher education institutions are placing increased focus on employability skills. Graduates of these institutions are employed by both the private and the public sector, and because these two sectors have different philosophical underpinnings, one would expect that they would focus on different employability skills. This assumption was however not supported by the findings of this paper which indicated that the private and public sector participants only differ in terms of their evaluation of self-responsibility and interpersonal skills of graduates. In order to ensure that graduates are industry-ready, further empirical research is recommended, particularly in relation to the improvement of current syllabi.

\section{References}

Alibeigi, A.H., \& Zarafshani, K. (2006). Are agricultural graduates meeting employers' expectations? A perspective from Iran. Perspectives in Education, 24(3): 53-61. 
Babes, M.S. (2009). Algeria towards a knowledge-based economy: developing knowledge economy strategies to improve competitiveness. Alexandria, Egypt: World Bank Development Institute.

Backhouse, J. (2010). Importance of research driven approaches to improving undergraduate success. (Paper presented at the Council on Higher Education's second colloquium on "Improving undergraduate success" held at Birchwood Hotel and OR Tambo Conference Centre, Johannesburg on the $5^{\text {th }}$ of March 2010).

Benson, V., Morgan, S. \& Filippaios, F. (2014). Social career management: social media and employability skills gap. Computers in Human Behaviour, 30: 519-525.

Bester, C., \& Boshoff, E. (2009). Perceptions of managers in the public sector regarding the relevance of training and education of entrants to the labour market. Tydskrif vir Geesteswetenskappe, 49(4): 728-739.

Bridgestock, R. (2009). The graduate attributes we've overlooked: enhancing graduate employability through career management skills. Higher Education Research and Development, 28(1): 31-44.

Campbell, A. (2010). Developing generic skills and attributes of international students: the (ir) relevance of the Australian University experience. Journal of Higher Education Policy and Management, 32(5): 487-497.

Chelechele, T.I. (2009). Skills development in the South African public service: problems and solutions. Journal of Public Administration, 44(1): 44-57.

Cranmer, S. (2006). Enhancing graduate employability: best intentions and mixed outcomes. Studies in Higher Education, 31(2): 169-184.

Cummings, J. (2010). Contextualised performance: reframing the skills debate in research education. Studies in Higher Education, 35(4): 405419.

De Jager, H.C. (2004). Employer expectations and prospective employee realities: A model to address the need for employable skills. Unpublished PhD thesis, North-West University, Vaal Triangle Campus.

De Lisle, J. (2011). The benefits and challenges of mixing methods and methodologies: lessons learned from implementing qualitatively led mixed methods research designs in Trinidad and Tobago. Caribbean Curriculum, 18: 87-120.

Freire Seoane, M.J., Teijeiro Álvarez, M., Pais Montes, C. (2011). Políticas educativas y empleabilidad: ¿Cuáles son las competencias más influyentes? Archivos Analíticos de Políticas Educativas, 19(28): 25-36.

Hauer, J. and Quill, T. (2011). Educational needs assessment, development of learning objectives, and choosing a teaching approach. Journal of Palliative Medicine, 14(4): 503-508.

Hennemann, S., \& Liefner, I. (2010). Employability of German geography graduates: the mismatch between knowledge acquired and competence required. Journal of Geography in Higher Education, 34(2): 215-230.

Hinchliffe, G.W., and Jolly, A. (2011). Graduate identity and employability. British Education Research Journal, 37(4): 563-584.

Jick, T.D. (1979). Mixing qualitative and quantitative methods: triangulation in action. Administrative Science Quarterly, 24(4): 602-611.

Jonck, P. (2014). A human capital evaluation of graduates from the Faculty of Management Sciences employability skills in South Africa. Academic Journal of Interdisciplinary Studies, 3(6): 265-274.

Jonck, P., \& Minnaar, R. (2015). Validating an employer graduate-employability skills questionnaire in the faculty of Management Sciences. Mediterranean Journal of Social Sciences, 6(2): 230-237.

Kroukamp. J.H. (2007). Public sector training in South Africa: Vehicle towards good governance: Fact or Fallacy? Conference Proceedings, Journal of Public Administration, 42(5): 1-8.

Le Van, C., Nguyen, T., Nguyen, M. and Luong, T.B. (2010). New technology, human capital, and growth in a developing country. Mathematical Population Studies, 17: 215-241.

May. T. (2011). Social Research: Issues, methods and process (4th ed.). Berkshire: Open University Press.

Matsepe, M.W. (2002). Adult education as an agent for social change: a case study in Lesotho. Unpublished Doctoral Thesis, University of South Africa, Pretoria.

Mclean, M., Abbas, A., \& Ashwin, P. (2012). Pedagogic quality and inequality in undergraduate degrees. Paper presented at "International Research Seminar: Higher Education and Development". June, in Bloemfontein, South Africa.

Mohan, C.R. (2013). First ever employability audit: Almost half of Indian graduates unemployable. Press Trust of India: New Delhi, Mon Jun 24 2013, 18:04 hrs. Retrieved from www.indianexpress.com/news/first-ever-employability-audit-almost-half-of-indian-graduatesunemployable/1133141/ on 23 August 2013.

Mohr, P., \& Seymore, R. (2012). Understanding micro-economics. Pretoria: Van Schaik Publishers.

Omar, N.H., Manaf, A.A., Mohd, R.H., Kassim, A.C., \& Aziz, K.A. (2012). Graduates' employability skills based on current job demand through electronic advertisement. Asian Social Science, 8(9): 103-110.

Pan, Y \& Lee, L. (2011). Academic Performance and Perceived Employability of Graduate Students in Business and Management - An Analysis of Nationwide Graduate Destination Survey. Procedia - Social and Behavioral Sciences, 25: 91-103.

Parker, B. \& Griesel, H. (2009). Graduate Attributes. A baseline study on South African graduates from the perspective of employers. Pretoria: Higher Education South Africa \& The South African Qualifications Authority.

Ramesh, G. \& Ramesh, M. (2010). The ACE of Soft Skills: Attitude, Communication and Etiquette for success. India: Pearson.

Selvadurai, S., Choy, E.A., \& Maros, M. (2012). Generic skills of prospective graduates from the employers' perspective. Asian Social Sciences, 8(12): 295-303.

Stice, M. (2011). A leader's introduction of rapid and radical change into an organization: A case study of Jack Welch and General Electric. PhD thesis. Washington DC: George Washington University.

Woldegiorgis, E.T., Jonck, P., \& Goujon, A. (2015). Regional higher education reform initiatives in Africa: A comparative analysis with the Bologna process. International Journal of Higher Education, 4(1): 241-253.

Yabuuchi, S., \& Chaudhuri, S. (2009). Skill formation, capital adjustment cost and wage inequality. Review of Urban and Regional Development Studies, 21(1): 2-13.

Yorke, M. \& Knight, P.T. (2006). Embedding employability into the curriculum. New York: The Higher Education Academy. 